15. Слабошицький М. Історичний дивосвіт Павла Загребельного (Шкіц до портрета). Дивослово. 2000. № 2. С. 57-59.

16. Фащенко В. Павло Загребельний. Київ, 1984. 206 с.

17. Чернов А. Щоб жити потрібні Вітчизна, свобода i пісня. Літературна Україна. 2014. № 33. С. 5.

18. Чумак Т. Проблема збереження духовності в романі Павла Загребельного «Диво». Українська література в загальноосвітній школі. 2004. № 10. С. $20-23$.

19. Шаховський С. Романи Павла Загребельного. Київ, 1974. 175 с.

DOI https://doi.org/10.30525/978-9934-26-039-1-24

\title{
ОСОБЛИВОСТІ ВІДБИТТЯ ТРАДИЦІЇ ВОЛОДИМИРА МАЯКОВСЬКОГО У ТВОРЧОСТІ МИХАЙЛА КУЛЬЧИЦЬКОГО
}

\author{
Козлова А. Г. \\ кандидат філологічних наук, дочент, \\ доиент кафедри зарубіжної літератури та слов'янських мов \\ Харківського національного педагогічного університету \\ імені Г. С. Сковороди \\ м. Харків, Украӥна \\ Козлов Є. Д. \\ кандидат філологічних наук, \\ доцент кафедри ділової іноземної мови та перекладу \\ Начіонального технічного університету \\ «Харківський політехнічний інститут» \\ м. Харків, Україна
}

Михайло Кульчицький - харківський поет, представник першого покоління радянських поетів, творчий шлях якого розпочався безпосередньо перед Другою світовою війною. I хоча загинув Кульчицький зовсім молодим (йому виповнилося лише 23 роки) i кількість творів, що лишилася нащадкам, невелика, але вірші поета увійшли до двохсоттомної «Бібліотеки всесвітньої літератури» (БВЛ) і перекладені багатьма мовами світу. Яскравий поетичний талант Кульчицького привернув до себе увагу сучасників поета, і вже багато років його творчість вивчається літературознавцями. Традиційно інформація про Кульчицького входить до оглядових статей, присвячених 
характеристиці творчості поетів, що загинули на фронті. Особлива роль у вивченні життя і творчої спадщини Кульчицького належить харківському досліднику Михайлу Красікову, який багато зробив також як текстолог, укладач і публікатор творів поета. При всьому тому деякі аспекти творчості Кульчицького досі зостаються невивченими, або такими, що залишаються на периферії дослідницької уваги.

Метою нашого дослідження $є$ характеристика особливостей сприйняття Михайлом Кульчицьким традиції Володимира Маяковського. Ця тема так чи інакше позначалася у літературознавчих роботах наших попередників, але досі не отримала глибокого і всебічного висвітлення.

Давид Самойлов у мемуарному нарисі «Кульчицкий и пятеро» зазначав, що «улюбленим поетом Кульчицького був Маяковський. Його, можливо, і можна було б вважати учителем Кульчицького. Але я в їхній поетиці, в манері будувати образ, у всій поетичній ході не бачу прямої подібності. Кульчицький багато переймав від Маяковського у віршах і в манері поведінки. Але талант він був іншого типу...» (тут і далі переклад українською наш. - А.К., Є.К.) [5]. В той же час Самойлов визнає наявність спадкоємного зв'язку «між поезією Маяковського і ЛЕФу i поезією Кульчицького», зауважуючи, що останній цінував свіжість і нетрадиційність віршу, оригінальність засобів художньої виразності [5].

Ми спробуємо довести, що традиція Маяковського позначилася на творчості Кульчицького багатовекторно, i, мабуть, не випадково Ліля Брік називала Кульчицького нащадком Маяковського.

Особистість i творчість Володимира Маяковського відіграють особливу роль у світогляді і творчості Михайла Кульчицкого. Михайло Красіков в статті ««Строка, оборванная... пулей»? Судьба наследия Михаила Кульчицкого как зеркало нашей эпохи» [1] наводить одну із «заповідей», що містяться в записнику молодого поета, - Говорити у віршах з майбутньою людиною, через голови редакторів $i$ колишніх рядків - і порівнює іiі з «божевільною мрією» Маяковського «дійти до майбутнього читача «через головы поэтов и правительств»« [1]. Таке зіставлення цілком виправдане, бо не складно помітити і формальну схожість, і лексичну відповідність, які дозволяють розглядати «заповідь» Кульчицького як алюзію до віршу Маяковського.

Ріднить поетів і відчуття відповідальності перед сучасниками i нащадками, i безпосереднє звернення до читача 3 майбутнього (Маяковський: Я сам расскажу о времени и о себе; Слушайте, товарищи потомки...; Кульчицький: Далекий друг! Года и версты / И стены книг библиотек / Нас разделяют. Шашкой Щорса / Врубиться в лучезарный 
век / Хочу. Чтоб, раскроивши череп / Врагу последнему и через / Него перешагнув, рубя, - / Стать первым другом для тебя) [2, с. 68]. Коли читаєш строки Кульчицького С высокой полки на врага / Я упаду тяжелой книгой [2, с. 69], на думку спадають сто томов ... nартийных книжек Маяковського («Во весь голос») і та книжкова полиця, на якій после смерти ... стоять почти что рядом творінням Маяковського i його великого попередника Пушкіна («Юбилейное»).

Зближує Кульчицького з Маяковським також патріотичний пафос поезії. Якщо лейтмотивом творчості Маяковського можуть служити слова: Я землю эту люблю, то, говорячи про Кульчицького, досить згадати його «поему про Росію» «Самое такое», де багато разів варіюється думка про любов поета до Батьківщини.

Багато спільного можна винайти у репрезентації обома поетами теми поетичної творчості, у розумінні ролі творця і призначення мистецтва. Показовим у зв'язку з цим $\epsilon$ використання Кульчицьким алюзії до відомого вислову Маяковського Театр - не отображающее зеркало, / $a$-увеличивающее стекло [4, с. 353]: Мой стих не зеркало - но телескоп $(« 194 \ldots$ г.») [2, с. 64].

Характерні для Маяковського зіставлення поезії із зброєю, військовою атрибутикою неодноразово зустрічаються й у Кульчицького (штылки; стихов угластые кастеты; почерк пули (литературы партизанов) та ін.). Яскравим прикладом може слугувати вірш «Дуэль»: Каждая строчка - это дуэль - / Площадка отмерена точно. / И строчка на строчку - шинель на шинель. / И скресты двух шпаг рифма строчек [2, с. 39]. Близкість сприйняття поетичної творчості обома поетами підкреслює й використання Кульчицьким у вірші «Баллада о комиссаре» (1940) цитати 3 віршу Маяковського «Господин «народный артист»«: Этот листок начинался словами, / Oт которых сморгнул офицерский глаз: / «И песня и стих - это бомба и знамя, / и голос певиа подыммает класс...» [2, с. 53]. Лексика, яку використовує в цьому вірші Кульчицький, - стишки, республика, халтура, эстеты, nроституты - такоже нагадує лексику віршів Маяковського, та й характер рими Кульчицького відсилає до рим Маяковського: республики - кубикам, будке - будто, «стоп» - авто, Сталин - кварталам, пригрезилась - поэзия, эстеты - кастеты и др.

Присутність українізмів у поемі Кульчицького «Самое такое» (частини IV «Я продолжал Россию» i VI «Губы в губы») разом 3 розташуванням віршів «драбинкою» і використанням слів (коммунизм) i рим (странии - отстранить), що характерні для творів Маяковського, відсилає до великого попередника Кульчицкого і його віршу «Долг 
Украине», де досить широко представлені українські лінгвокультуреми, характерні для української мови форми слів і використовується цитата із українського перекладу «Інтернаціонала»: горилкой, товарищ москаль, анекдотов украинской мовы, эта мова величава и проста: / «Чуешь, сурмы заграли, / час расплаты настав...» та ін. У харків'янина Кульчицького подібних прикладів більше: зашиток, травень, липень, та ü ще як блакитные облака, прохаю, кохаю, любый; не випадково він каже: моё украинское тихое слово [2, с. 96].

Однією 3 найбільш наочних і неодноразово відмічених дослідниками особливостей стилю Маяковського $€$ велика кількість слів із збільшувальними і зменшувальними суфіксами, які зустрічаються протягом всього його творчого шляху. Такі словоформи активно використовуються й Кульчицьким: стишки, темнейший (князь), понятнейшее (слово). На дериваційному рівні роль подібних «знаків» виконує прагнення до словотворчості. Кульчицький нерідко використовує оказіональну лексику, причому він, як і Маяковський, не створює слів, які б не мали змістового наповнення, або $є$ важкими для розуміння: непоэт, шарзе́мец, вокругшарный (ветер), ярковыпеченные (рубли), (павлин) прохвостый, всепонятный (язык), разнаипоследних (атак), (водой) ломозубой и др.

Серед рис формальної схожості, що зближують поезію Кульчицького 3 поезією Маяковського, треба назвати розташування віршів «драбинкою», використання своєрідних рим і ритму. Відомо, що у Маяковського зустрічаються різні види рим, що його рими дуже виразні і різноманітні, серед них є прості, складні, складані, усічені, з різним наголосом i навіть панторима. Рими Кульчицького близькі римам Маяковського: Бордо - бедро, революиия - с блюдия, остаток - статуй, во сне - снег, ветер - на свете, сердиза - зеркальца, снежинки Дзержинского, маем - сдуваемый, оставленной - за Таллином, атак танк, республики - кубикам, лейтенант - налейте нам, топографию по гравию, орденов - Бородино, нация - в девятнадиатом та ін.

Таким чином, поетів зближує глибокий патріотизм, однакове розуміння особливостей поетичної праці та ролі поета у суспільстві, прагнення до активної словотворчості, використання «непоетичної» лексики та українізмів, багате різноманіття рим, розташування віршів «драбинкою». Кульчицький наводить у своїх віршах цитати із творів Маяковського, використовує алюзії до них. Тобто традиція Маяковського виявляє себе на різних рівнях художньої системи Кульчицького - i на змістовому, і на формальному. 


\title{
Література:
}

1. Красиков М. «Строка, оборванная... пулей»? Судьба наследия Михаила Кульчицкого как зеркало нашей эпохи. URL: http://kharkovhumanit.narod.ru/Esse2.html.

2. Кульчицкий В.М. Вместо счастья: Стихотворения. Поэмы. Воспоминания о поэте. Харьков: Прапор, 1991. 270 с.

3. Маяковский В.В. Полное собрание сочинений: в 13 т. М.: Государственное издательство художественной литературы, 1958. Т. 7. Стихотворения, очерки. 1925-1926. 1958. 535 с.

4. Маяковский В.В. Полное собрание сочинений: в 13 т. М.: Государственное издательство художественной литературы, 1958. Т. 11. Пьесы, киносценарии. 1926-1930. 1958. 703 с.

5. Самойлов Д. Перебирая наши даты. URL: https://coollib.net/b/ 237451-david-samoylovich-samoylov-perebiraya-nashi-datyi/read.

DOI https://doi.org/10.30525/978-9934-26-039-1-25

\section{ФЕРДИНАНД ФОН ШИРАХ ЯК НОВА ПОСТАТЬ У СУЧАСНІЙ НІМЕЦЬКІЙ ЛІТЕРАТУРІ НА ЗАНЯТТЯХ З ОСНОВНОЇ ІНОЗЕМНОЇ МОВИ Й ПЕРЕКЛАДУ ЗІ СТУДЕНТАМИ ВІДДІЛЕННЯ НІМЕЦЬКОЇ ФІЛОЛОГІї}

\author{
Лисецька Н. Г. \\ кандидат філологічних наук, доцент, \\ дочент кафедри німецької філологіі \\ Волинського національного університету імені Лесі Украӥнки \\ м. Луиькк, Україна
}

Сучасна німецька література deutsche Gegenwartsliteratur [1; 2] представлена багатьма відомими іменами: Thomas Brussig, Elfriede Elinek, Felicitas Hoppe, Daniel Kehlmann, Bernhard Schlink, Ingo Schulze, Patrick Süskind, Uwe Tellkamp, Uwe Timm та ін. Проте до авторів початку третього тисячоліття належить також нове ім'я - Фердинанда фон Шираха. Для студентів факультетів іноземної філології твори відомого юриста можуть стати в пригоді при формуванні фахових компетентностей для поглиблення знань німецькомовного художнього дискурсу з фокусом на правову систему Німеччини, що свідчить про актуальність розвідки. Мета наукової праці - ознайомлення з творчістю Фердинанда фон Шираха. 